Available online at GSC Online Press Directory

GSC Biological and Pharmaceutical Sciences

e-ISSN: 2581-3250, CODEN (USA): GBPSC2

Journal homepage: https://www.gsconlinepress.com/journals/gscbps

(RESEARCH ARTICLE)

\title{
Evaluating the effect of ethanol leaf extract of Gongronema latifolium on some reproductive hormones of male Wistar rats
}

\author{
Dasofunjo K ${ }^{*}$, Asuk AA and Nku CI \\ Department of Medical Biochemistry, Okuku Campus, Cross River University of Technology, Cross River State, Nigeria.
}

Publication history: Received on 14 September 2020; revised on 22 September 2020; accepted on 25 September 2020

Article DOI: https://doi.org/10.30574/gscbps.2020.12.3.0297

\begin{abstract}
This research was aimed at evaluating the effect of ethanol leaf extract of Gongronema latifolium on some reproductive hormones of male Wistar rats. Eighteen (18) male Wistar rats weighing 120-200 g were divided into three (3) groups of six (6) animals each. The animals were allowed to undergo acclimatisation period for seven days before the start of the research. Animals in group A served as the control, while group B and C were administered 100 and $200 \mathrm{mg} / \mathrm{kg}$ body weight of ethanol extract of $G$. latifolium, respectively. The administration was performed for 14 days. Twelve hours after the last administration, the rats were sacrificed and cardiac puncture procedure was used to collect the blood for some reproductive hormonal analysis. The extract produced a $(P<0.05)$ significant increase in serum testosterone, follicle stimulating hormone, and luteinizing hormone respectively at $100 \mathrm{mg} / \mathrm{kg}$ and $200 \mathrm{mg} / \mathrm{kg} \mathrm{body}$ weight compared to normal control and progesterone produced a significant $(P<0.05)$ decrease in all experimental groups compared with normal control. The extract was found to contain alkaloids, saponins, flavonoids, steroids, triterpenoids, tannins, and glycosides at varying concentrations. The rich phytochemicals in the extract of Gongronema latifolium strongly contribute in enhancing sexual health and libido in males. It is possible to use the plant extract in the management of erectile related dysfunction.
\end{abstract}

Keywords: Erectile dysfunction; FSH; Libido; LH; Testosterone

\section{Introduction}

Sex hormones are specific regulatory molecules which modulate reproduction, growth and development, as well as the maintenance of internal environments and the production, use and storage of energy [1]. They are regulators of reproductive functions. Sex hormones, like periodontal tissue, have important effects on the nervous and cardiovascular systems and are significant determinants of the growth and integrity of the skeleton and oral cavity [2, 3]. The hypothalamic-pituitary - gonadal axis is known as the male reproductive hormone axis. It consists of three major components: the hypothalamic, pituitary and testicular glands [4,5]. This axis works regularly to provide the right concentration of hormones for male sexual development and functions. Any abnormality in the system can lead to infertility or sexual dysfunction [6, 7]. If the brain is unable to produce gonadotropic releasing hormone (GnRH), this disorder results in a lack of testosterone and thereby inhibits spermatogenesis $[8,9]$. The lack of GnRH causes a group of disorders known as hypogonadotropic hypogonadism (hypogonatropism) [10,11]. Gonadotropin-releasing hormone deficiency treatment choices include the use of sex hormones, gonadotropins and gonadotropin-releasing hormone injections. Testosterone injections are mainly used to improve testicular growth, normalise testosterone concentration, and stimulate the development of secondary sexual traits [12]. Similarly, pituitary's inability to produce sufficient amounts of luteinizing hormone and follicular stimulating hormone results in a failure to stimulate the synthesis of testosterone and spermatozoa or sexual dysfunction $[13,14]$

\footnotetext{
* Corresponding author: Dasofunjo K

Department of Medical Biochemistry, Okuku Campus, Cross River University of Technology, Cross River State, Nigeria.

Copyright $(2020$ Author(s) retain the copyright of this article. This article is published under the terms of the Creative Commons Attribution Liscense 4.0.
} 
Erectile dysfunction is becoming a major calamity in Africa. It is slowly eating deep into the life of individuals' especially in married homes and is causing problems that have led to broken homes, separation and divorce not only in Africa but across the globe. The global estimated prevalence has been on the rise. It has been projected that the number of men with this condition will rise to 322 million by 2025 and $35 \%-47 \%$ in Nigeria [15].

While the use of allopathic pharmaceutical products has demonstrated a substantial improvement in the treatment of sexual disorders, a large number of side effects occur at the same time, including heart rhythm disturbances, suicidal impulses, psychiatric disorders and tremors [16]

As any agent capable of stimulating the sexual urge, inducing venereal desire and increasing pleasure and results, an aphrodisiac is defined [17]. Typically, aphrodisiacs are divided into two groups: preparations for psycho-physiological stimulation (olfactory, visual, tactile and aural) and internal agents, primarily derived from plants (food, alcohol and love potion) [17]. Side effects are correlated with various synthetic substances widely used to enhance sexual desire and efficiency, such as dopamine, amyl nitrite, and sildenafil citrate [18]. In developing countries, the search for new compounds from medicinal plants is being intensified, due to low side effects, easy availability, low cost, and high efficacy.

African medicinal plants such as Gongronema latifolium are known for both nutritional and medicinal value. The tropical rainforest plant Gongronema latifolium (Utazi) belongs to the Asclepiadaceae family and to the genus Gongronema [19]. It is an edible plant which, when cut, produces milky latex with a green leaf, yellow flower and stem. In particular, when eaten fresh, it has a distinctive sharp, bitter and slightly sweet taste.

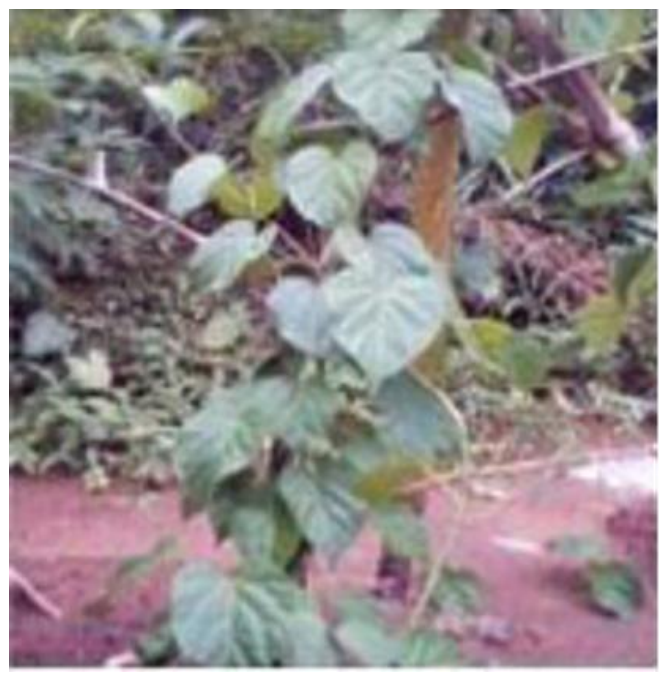

Figure 1 The plant of Gongronema latifolium

It is then taken as an aphrodisiac and as a purgative for colic and stomach pain and to treat symptoms of worm infection [22]. Due to its composition of different active chemicals, Gongronema latifolium is believed to possess good medicinal qualities. Some of the medicinal values of Gongronema latifolium have also been scientifically validated. Therefore, since sexual hormones play a significant role in reproduction, this present study determines the effect of Gongronema latifolium on some reproductive hormones of male Wistar rats.

\section{Material and methods}

\subsection{Plant material}

Fresh leaves of Gongronema latifolium were collected from Obudu, Obudu Local Government Area, Cross River State, Nigeria. The leaves were taken to the Department of Botany, University of Calabar for identification and authentication. The Voucher number Herb/Bot/UCC/611 has been deposited for future reference at the Department's Herbarium.

\subsection{Preparation of plant material}

Fresh leaves of Gongronema latifolium were air-dried at room temperature for twenty (20) days, macerated and pulverised into powdery form using the blender and then sieved. 


\subsection{Ethanol extraction}

Three hundred (300) g of powdered Gongronema latifolium leaves were dissolved in $1200 \mathrm{~mL}$ of ethanol water for $72 \mathrm{~h}$ in a refrigerator. After that, it was filtered with muslin cloth and filtered using Whatman filter No1. The filtrate was evaporated to dryness and the percentage yield was calculated and reconstituted into dosage and administered into rats.

\subsection{Phytochemical screening}

The qualitative phytochemical screening of Gongronema latifolium leaf was determined by the methods of [23, 24]

\subsection{Experimental animals}

Eighteen (18) Wistar albino rats (120-200) g were obtained from the Animal Holding Unit of the Department of Medical Biochemistry, Cross River University of Technology, Okuku Campus, Yala Local Government Area, Cross River State, Nigeria. The animals were allowed to undergo acclimatisation period for seven days before the start of the research.

The rats were housed in a plastic cage. The animals were kept in well-ventilated room at temperature and relative humidity of $29 \pm 2{ }^{\circ} \mathrm{C}$ and $70 \%$ respectively, with $12 \mathrm{~h}$ natural light-dark cycle and were allowed free access to standard feed and water ad libitum. Constant cleaning and removal of faeces and spilt feeds from cages was done daily to maintain good hygiene.

\subsection{Experimental design}

The experiment was conducted using Eighteen (18) male Wistar rats, ranging from 120-200 g. Group A served as the control, group B was administered with $100 \mathrm{mg} / \mathrm{kg}$ body weight of ethanol extract of G. latifolium, group C $200 \mathrm{mg} / \mathrm{kg}$ body weight of the extract, The vehicle and extract were orally administered after 12 days of administration all rats were fasted for $24 \mathrm{~h}$, the rats were sacrificed and cardiac puncture procedure was used to collect the blood.

\subsection{Hormonal assay}

Serum testosterone was estimated using Rapid lab kit (United Kingdom) for the enzyme linked immunosorbent assay (ELISA) while serum FSH, LH and progesterone were estimated using Dialab Kit (Austria) for ELISA for quantitative determination of FSH in the serum.

\section{Results}

The result depicts that the leaves of $G$. latifolium contain alkaloids, saponins, flavonoids, steroids, triterpenoid, tannins, glycosides at varying concentrations and the absence of both phlobatanins and anthraquinones (Table 1).

Table 1 The phytochemical screening of G. latifolium leaf

\begin{tabular}{|c|c|}
\hline Phytochemicals & G. Iatifolium \\
\hline Alkaloids & ++ \\
\hline Saponins & +++ \\
\hline Flavonoids & ++ \\
\hline Steroids & + \\
\hline Tannins & + \\
\hline Triterpenoids & + \\
\hline Glycosides & ++ \\
\hline Phlobatanins & - \\
\hline Antraquinones & - \\
\hline
\end{tabular}


The result also indicates the effect of ethanol extract of $G$. latifolium on some reproductive hormones following extract administration, it was observed that the extract produced a significant increase $(\mathrm{P}<0.05)$ in the concentration of serum follicle stimulating hormone (FSL) and luteinizing hormone (LH) at $100 \mathrm{mg} / \mathrm{kg}$ and $200 \mathrm{mg} / \mathrm{kg}$ body weight compared to normal control (Figure 2).

Likewise, the extract produced a significant increase $(\mathrm{P}<0.05)$ in serum testosterone at both $100 \mathrm{mg} / \mathrm{kg}$ and $200 \mathrm{mg} / \mathrm{kg}$ body weight compared with the normal control. More so, the extract produced a significant decrease $(\mathrm{P}<0.05)$ in serum progesterone in the experimental groups compared with the control (Figure 3).

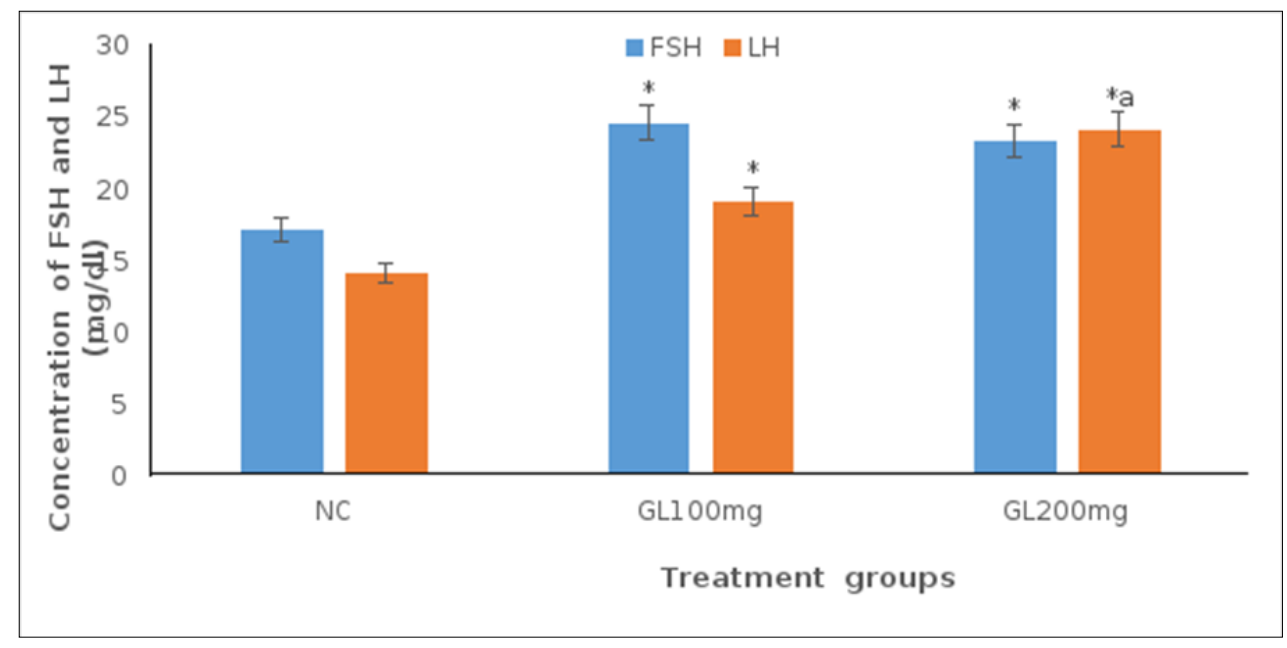

Figure 2 Effect of Gongronema latifolium ethanol extract on Follicle stimulating hormone (FSL) and Luteinizing hormone (LH) of experimental animals. Values are expressed as means + SEM; $\left(n=5\right.$ rats per group). ${ }^{*}=$ significantly different from NC ( $\mathrm{P}<0.05)$, a = significantly different from GL100mg $(\mathrm{P}<0.05)$. Legend: NC, normal control that received normal saline; GL100mg = Group that received $100 \mathrm{mg} / \mathrm{kg}$ b.w ethanol extract of G. latifolium, GL200 = Group, which received $200 \mathrm{mg} / \mathrm{kg}$ b.w ethanol extract of $G$. latifolium.

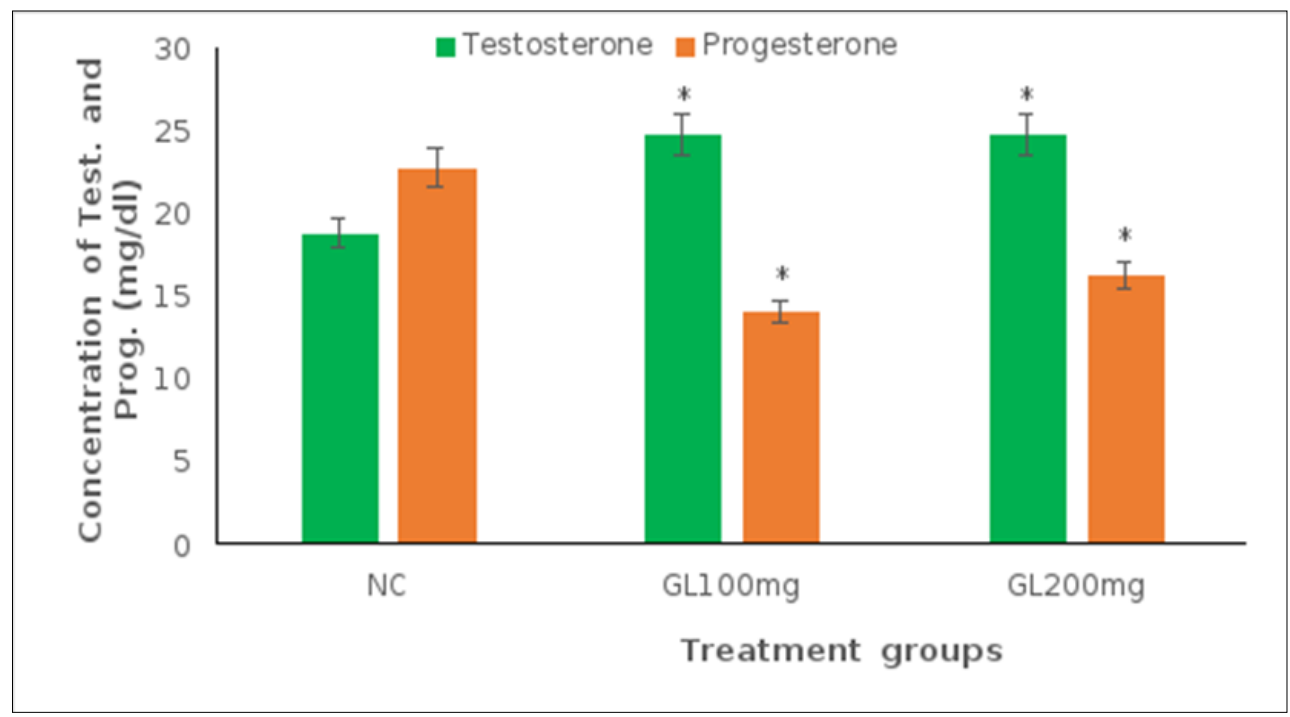

Figure 3 Effect of Gongronema latifolium ethanol extract on testosterone and progesterone of experimental animals. Values are expressed as means $\pm \mathrm{SEM}$; $\left(\mathrm{n}=5\right.$ rats per group). ${ }^{*}=$ significantly different from $\mathrm{NC}(P<0.05)$. Legend: $\mathrm{NC}$ $=$ normal control that received normal saline, GL100mg $=$ Group that received $100 \mathrm{mg} / \mathrm{Kg}$ b.w ethanol extract of $G$. latifolium, GL200 = Group that received $200 \mathrm{mg} / \mathrm{Kg}$ b. w ethanol extract of $G$. latifolium. 


\section{Discussion}

Medicinal plants and other ethnobotanical can stimulate reproductive hormones due to the activity of the phytonutrients in the herbal therapies or by either binding to hormone receptors, which result in conformational changes that will enhance the physiological function of the hormones or bind to enzymes that are involved in the synthesis of such reproductive hormones.

It has been reported that several phytochemicals have been implicated in enhancing sexual function in animal models. For example, saponins are responsible for aphrodisiac activity in Fadogia agrestis (Schweinf. Ex Hiern) and Tribulus terrestris (Linn.) so are alkaloids in Pausinystalia yohimbe (K. Schum) and Microdesmis keayana (J. Leonard) [25]. Similarly, pro sexual stimulatory property of Mondia whitei Hook (Skeels) has also been attributed to its steroid and triterpene contents [26]. These bioactive agents display aphrodisiac activity either by increasing androgen biosynthesis and secretion or by acting directly on the central nervous system in order to modulate the function of animal neurotransmitters and gonadal tissues. Specifically, saponins enhance androgen production [27] whereas alkaloids increase the dilation of blood vessels in the sexual organs, or increase nitric oxide that plays a key role in central erection and central sexual stimulation [28] Interestingly, some of these phytochemicals such as saponins and steroids were also detected in the leaf extract in this study that suggests that they are responsible in enhancing sexual behaviour by either binding to hormone receptors, resulting in a conformational change that will enhance the physiological function of the hormones or bind to enzymes that are involved in the synthesis of such reproductive hormones to enhance its production. Moreover, it has been documented that by boosting testosterone production and preventing metabolic degradation, flavonoids facilitate male sexual behaviour [29]. Terpenoids are associated with the stimulation of penile erection and the enhancement of the sexual performance [30]. Kim et al [31] demonstrated that saponin facilitated the relaxation of the corpus cavernosum muscles by stimulating the L-arginine/nitric oxide pathway. These bioactive components affect the central nervous system by activating neurotransmitters or the periphery by stimulating the release of nitric oxide [32]. Therefore, it appears that phytochemical content present in Grongolema latifolium have androgen stimulatory action responsible for the increase in sex hormones, which enhance its sex-enhancing activity and spermatogenesis.

Testosterone is a male hormone with significant impact on spermatogenesis [33]. Leydig cells of the testicles secrete testosterone, the adrenals and ovaries, and is the most important androgen secreted into the blood [34, 35]. Testosterone, deficiency is presented with delayed puberty or regression of previously established male characteristics that depend on testosterone, such as hair distribution, potency, and libido. An elevated level of testosterone has been associated with a moderate but significant increase in sexual desire and penile function [36]. Clinical data on testosterone show that a slightly increased testosterone level in adult males, results in an enhanced sexual desire and arousability [37]. The level of testosterone has been reported to be related to LH and FSH such that increase in the levels of the gonadotropins results in a corresponding increase in testosterone [38]. In this present research work, the observed increase in serum testosterone suggests that the extract possesses a sex enhancing potential due to the presence of phytoconstituent such as flavonoids and alkaloid or saponin.

FSH stimulates testosterone spermatozoa development and promotes seminiferous tubule formation. FSH is responsible for the development, growth, pubertal maturation and reproductive processes of the human body [39]. Excess secretion of FSH is responsible for early puberty, whereas deficiency causes infertility and underdevelopment of gonads. From this study, the observed increase in serum FSH at $100 \mathrm{mg} / \mathrm{kg}$ and $200 \mathrm{mg} / \mathrm{kg}$ body weight indicates that the extract improved secondary sexual characteristics, sexual health with libido.

LH stimulates the production of testosterone from Leydig cells in males. Decreased secretion of LH can result in the breakdown of gonadal function (hypogonadism). In males, this disorder is usually manifested as failure in the development of normal numbers of sperm. In females, amenorrhoea is commonly observed. FSH and LH are collectively responsible for the development and maintenance of secondary sexual character in males [40, 41,42]. From this work, increase in serum LH in all experimental groups suggests that the extract aid gametogenesis, via the hypothalamic axis.

Progesterone is an endogenous sex hormone and progestogen involved in humans and other species' menstrual cycle, pregnancy, and embryogenesis [43]. Greater than normal levels indicate pregnancy. Adrenal or ovarian cancer, molar pregnancy, or overproduction of hormones by the adrenal glands may also be demonstrated by elevated levels. Lower than normal levels indicate amenorrhoea. Abnormally low levels of progesterone can also cause problems with ovulation. From this work, the decrease in serum progesterone following the administration of the extract acknowledges the fact that the plant extract increases libido in males and not females as progesterone activity is mainly associated with females. 


\section{Conclusion}

Conclusively, the extract of Gongronema latifolium enhances sexual health and libido in males. It is possible to be used in the management of erectile related dysfunction.

\section{Compliance with ethical standards}

\section{Acknowledgments}

The authors of this research study wish to appreciate the technical assistance of Mr Obogo Ezikiel of the Department of Medical Biochemistry, Cross River University of Technology, Okuku Campus, Nigeria.

\section{Disclosure of conflict of interest}

The authors have declared no conflict of interest.

\section{Statement of ethical approval}

Ethical approval for the study was obtained from the Faculty of Basic Medical Science Animal Research Ethical Committee of Cross River University of Technology, Calabar, Nigeria (approval number FBMS/CRUTECH/20/018).

\section{References}

[1] Mascarenhas P, Gapski R, Al-Shammari K, Wang HL. Influence of sex hormones on the periodontium. Journal of Clinical Periodontology. 2003; 30: 671-681.

[2] Lorenzo J. A new hypothesis for how sex steroid hormones regulate bone mass. Journal of Clinical Investigation. 2003; 111(11): 1641-1643.

[3] McCauley LK, Tözüm TF, Rosol TJ. Estrogen receptors in skeletal metabolism: lessons from genetically modified models of receptor function. Critical Review in Eukaryote Gene Expression. 2002; 12(2): 89-100.

[4] Zouboulis CC, Degitz K. Androgen action on human skin - from basic research to clinical significance. Experimental Dermatology. 2004; 13(4): 5-10.

[5] Kuiri-Hänninen T, Sankilampi U, Dunkel L. Activation of the hypothalamic pituitary-gonadal axis in infancy: minipuberty. Hormones Research in Paediatrics. 2014; 82(2): 73-80.

[6] Costanzo P, Suárez S, Scaglia H, Zylbersztein C, Litwak L, Knoblovits P. Evaluation of the hypothalamic-pituitarygonadal axis in eugonadal men with type 2 diabetes mellitus. Andrology. 2014; 2(1): 117-124.

[7] Tsatsanis C, Dermitzaki E, Avgoustinaki P, Malliaraki N , Mytaras V, Margioris AN . The impact of adipose tissuederived factors on the hypothalamic-pituitary-gonadal (HPG) axis. Hormones. 2015; 14(4): 549-562.

[8] Lucas X. Clinical use of deslorelin (GnRH agonist) in companion animals: a review. Reproduction in Domestic Animal. 2014; 49: 64-71.

[9] Monaco D, Fatnassi M, Padalino B, Aubé L, Khorchani T, Hammadi M, Lacalandra GM . Effects of a GnRH administration on testosterone profile, libido and semen parameters of dromedary camel bulls. Research in Veterinary Science. 2015; 102: 212-216.

[10] Cejko BI, Żarski D, Judycka S, Kucharczyk D, Sarosiek B, Kowalski RK . Effect of two commercial preparations containing different GnRH analogues with dopamine antagonists on barbell Barbus barbus (L.) sperm quantity and quality. Aquaculture International. 2014; 22(1): 97-109.

[11] Ullah H, Ambreen A, Ahsan N, Jahan S. Bisphenol S induces oxidative stress and DNA damage in rat spermatozoa in vitro and disrupts daily sperm production in vivo. Toxicology and Environmental Chemistry. 2017; 99(5-6): 953-965.

[12] Kiezun M, Smolinska N, Maleszka A, Dobrzyn K, Szeszko K, Kaminski T. Adiponectin expression in the porcine pituitary during the estrous cycle and its effect on LH and FSH secretion. American Journal of Physiology Endocrinology and Metabolism. 2014; 307(11): E1038-E1046.

[13] Wdowiak A, Raczkiewicz D, Stasiak M, Bojar I. Levels of FSH, LH and testosterone, and sperm DNA fragmentation. Neuroendocrinology Letter. 2014; 35(1): 73-79. 
[14] Ujah GA, Nna VU, Agah M I, Omue LO, Leku CB, Osim EE. Effect of quercetin on cadmium chloride-induced impairments in sexual behaviour and steroidogenesis in male Wistar rats, Andrologia. 2017; 50(3): 34-39.

[15] Uboh G, Adebayo AA, Ademosun AO, Abegunde OA. Aphrodisiac effect of Hunteria umbellata seed extract: Modulation of nitric oxide level and arginase activity in vivo. Pathophysiology. 2019; 26: 39-47.

[16] Watcho P, Modeste WN, Albert K, Carro-Juarez M. Dracaena arborea extracts delay the pro-ejaculatory effect of dopamine and oxytocin in spinal male rats. Int J Impot Res. 2014; 26: 213-217.

[17] Ugochukwu NH, Babady ME. Antihyperglycemic effect of aqueous and ethanolic extracts and Gongronema latifolium leaves on glucose and glycogen metabolism in livers of normal and streptozotcinic induced diabetic rats. Life Science. 2002; 73(15): 1925-1938.

[18] Eleyinmi AF. Chemical composition and antimicrobial activity of Gongronema latifolium. Journal of Zhejiang University Science Bulletin. 2007; 8(5): 352-358.

[19] Morebise O, Fafunso MA. Antimicrobial and phytotoxic activities of saponin extracts from two Nigerian edible medicinal plants. Biokemistri. 1998; 8(2): 69-77.

[20] Ugochukwu NH, Babady ME. Antioxidant effects of Gongronema latifolium in hepatocytes of rat models of noninsulin dependent diabetes mellitus. Fitoterapia. 2003; 73(7-8): 612-618.

[21] Trease GE, Evans WC. In: 'Textbook of Pharmacognosy' (Trease G. E. and Evans, W. C. ed.) 1989; 19-21.

[22] Harborne JB. In: 'A Guide to Modern Techniques of Plant Analysis' (Harborne, J. B. ed.). $1984 ; 192$.

[23] Yakubu MT, Afolayan AJ. Effect of aqueous extract of Bulbine natalensis (Baker) stem on the sexual behaviour of male rats. Int. J. Androl. 2009; 32: 629-636.

[24] Yakubu MT, Akanji MA, Oladiji AT. Aphrodisiac potentials of aqueous extract of Fadogia agrestis (Schweinf, Ex Heirn) stem in male albino rats. Asian J. Androl. 2005; 7: 399-404.

[25] Drewes SE, George J, Khan F. Recent findings on natural products with erectile-dysfunction activity. Phytochemistry. 2003; 62: 1019-1025.

[26] Gauthaman K, Adaikan PG. The hormonal effects of Tribulus terrestris and its role in the management of male erectile dysfunction-an evaluation using primates, rabbits and rats. Phytomed. 2008; 15: 44-54.

[27] Graham C. Reproductive Biology of the Great Apes: Comparative and Biomedical Perspectives. Elsevier. 2012; 2: $179-186$.

[28] Jian Feng C, Peng Ying Z, Cheng Wei X, Tao Tao H, Yun Gui B, Kao Shan C. Effect of aqueous extract of Arctium lappa L. (burdock) roots on the sexual behaviour of male rats. BMC Complement Altern Med. 2012; 12: 1-8.

[29] Hnatyszyn O, Moxatelli V, Rondina R, Costa M, Arranz C, Belaszczuk A. Flavonoids from Achyzocline satureiodes with relaxant effects on the smooth muscle in Guinea pig corpus cavernosum. Phytomedicine. 2004; 11: 366369.

[30] Kim HJ, Woo DS, Lee G, Kim JJ. The relaxation effects of ginseng saponin in rabbit corporal smooth muscle, is it a nitric oxide donor? Br J Urol. 1998; 82: 744-748.

[31] Carro-Juárez M, Cervantes E, Cervantes-Méndez M, Rodríguez-Manzo G. Aphrodisiac properties of Montanoa tomentosa aqueous crude extract in male rats. Pharmacol Biochem Behav. 2004; 78: 129-134.

[32] Bianchi VE. The Anti-Inflammatory Effects of Testosterone. Journal of the Endocrine Society. 2019; 3(1): 91-107.

[33] Amanatkar HR, Chibnall JT, Seo BW, Manepalli JN, Grossberg GT. Impact of exogenous testosterone on mood: a systematic review and meta-analysis of randomized placebo-controlled trials. Annals of Clinical Psychiatry. 2014; 26(1): 19-32.

[34] Mansoureh E, Mehrdad M, Akbar K, Aliasghar PD .The effects of frankincense's hydro alcoholic extract on pituitary-gonadal axis in female mice. Journal of Chemical and Pharmaceutical Research. 2016; 8(2): 697-700.

[35] Gauthaan K, Adaikan PG, Prasada RNV. Aphrodisiac properties of Tribulus terrestris extract (Protodioscin) in normal and castrated rats. Life Sci. 2002; 71: 1385-1396.

[36] Vingren JL, Kraemer WJ, Ratamess NA, Anderson JM, Volek JS, Maresh CM. Testosterone physiology in resistance exercise and training: the up-stream regulatory elements. Sports Medicine. 2010; 40(12): 1037-1053. 
[37] Valdes-Socin H, Daly AF, Beckers A. Luteinizing Hormone Deficiency: Historical Views and Future Perspectives. Austin Andrology. 2017; 2(1): 1015-1020.

[38] Jameson JL De Groot LJ. Endocrinology: Adult and Pediatric E-Book. Elsevier Health Sciences. 2015; 2: 21-79.

[39] Jiang C, Zuo F, Wang Y, Lu H, Yang Q, Wang J. Progesterone Changes VEGF and BDNF Expression and Promotes Neurogenesis after Ischemic Stroke. Molecular Neurobiology. 2017; 54(1); 571-581.

[40] Corradi PF, Corradi RB, Greene LW. Physiology of the hypothalamic pituitary gonadal axis in the male. Urologic Clinics. 2016; 43(2): 151-162.

[41] Choi SJ. Use of progesterone supplement therapy for prevention of preterm birth: review of literatures. Obstetric and Gynecology Science. 2017; 60(5): 405-420.

[42] Dasofunjo K, Asuk AA, Ezugwu HC, Nwodo OFC, Olatunji TL. Aphrodisiac Effect of Ethanol extract of Piliostigma thonnigii Leaf on male Wister Rats. Journal of Applied Pharmaceutical Science. 2013; 3(10): 130-135. 